\title{
Review
}

\section{Stemming the Hype: What Can We Learn from iPSC Models of Parkinson's Disease and How Can We Learn It?}

\author{
Benjamin Meir Jacobs* \\ Magdalen College, Oxford University, Oxford, UK
}

\begin{abstract}
Parkinson's disease (PD) is a prevalent and debilitating neurodegenerative disorder for which there are no available cures. PD pathogenesis is poorly understood because appropriate animal and in vitro models are lacking. The development of induced Pluripotent Stem Cells (iPSCs) has allowed researchers to generate disease-specific dopaminergic neurons in vitro by reprogramming skin cells from patients with the disease. It is hoped that this unprecedented access to PD patients' neurons will yield mechanistic insights into PD pathogenesis, a platform for drug screening, and a means of early diagnosis. In this article I critically evaluate the current usage of iPSCs in PD research. I first outline the iPSC paradigm and emphasise the benefits of this approach for modelling PD. I then ask what we can learn from the iPSC-based studies done to date. I argue that these studies have not been particularly informative when considered as an isolated body of evidence. I suggest that the limitations of this technology can be overcome, and I conclude that iPSCs have the potential to be an extremely useful tool in PD research. However, they will never be a panacea and should continue to be used in concert with other in vitro and animal models.
\end{abstract}

Keywords: Disease model, in vitro, induced pluripotent stem cells, neurodegeneration, Parkinson's disease, stem cell

\section{INTRODUCTION}

Parkinson's disease (PD) is the second most common neurodegenerative disorder after Alzheimer's disease (AD), affecting approximately $1 \%$ of people over 60 [1]. It is a debilitating, progressive condition characterised by motor and non-motor symptoms resulting from the loss of dopaminergic neurons (DAn) from the substantia nigra, and of neurons from other brain regions [2]. As age is the major risk factor for developing PD and the world's population is ageing, this disease is rapidly becoming a public health issue.

And yet there are no cures available for PD, primarily because our understanding of the basic processes that underlie disease progression is inadequate. Progress has been hampered by the paucity of appropri-

${ }^{*}$ Correspondence to: Benjamin Meir Jacobs, Magdalen College, Oxford University, High Street, Oxford, OX1 4AU, UK. E-mail: Ben.jacobs@magd.ox.ac.uk. ate models. Important insights have come from work on patients' post-mortem samples, pharmacologicallylesioned animals, transgenic animals, and various in vitro models, but these systems have not provided us with a clear understanding of PD pathogenesis. Finding models that faithfully recapitulate the early events in human PD is essential for developing effective treatments.

The development of induced Pluripotent Stem Cells (iPSCs) has spawned a new approach to modeling PD. iPSCs can be derived from the somatic cells (e.g., skin cells) of patients and control subjects, differentiated into specific neuronal subtypes, and studied in a dish $[3,4]$. This article will ask what iPSC models have taught us about PD and what steps can be taken to get more out of this technology. I argue that iPSC-derived neurons are an exciting prospect for PD research; the initial results are promising, and many of the teething issues with this technology are surmountable. I conclude that, if used cautiously and as a complement to 


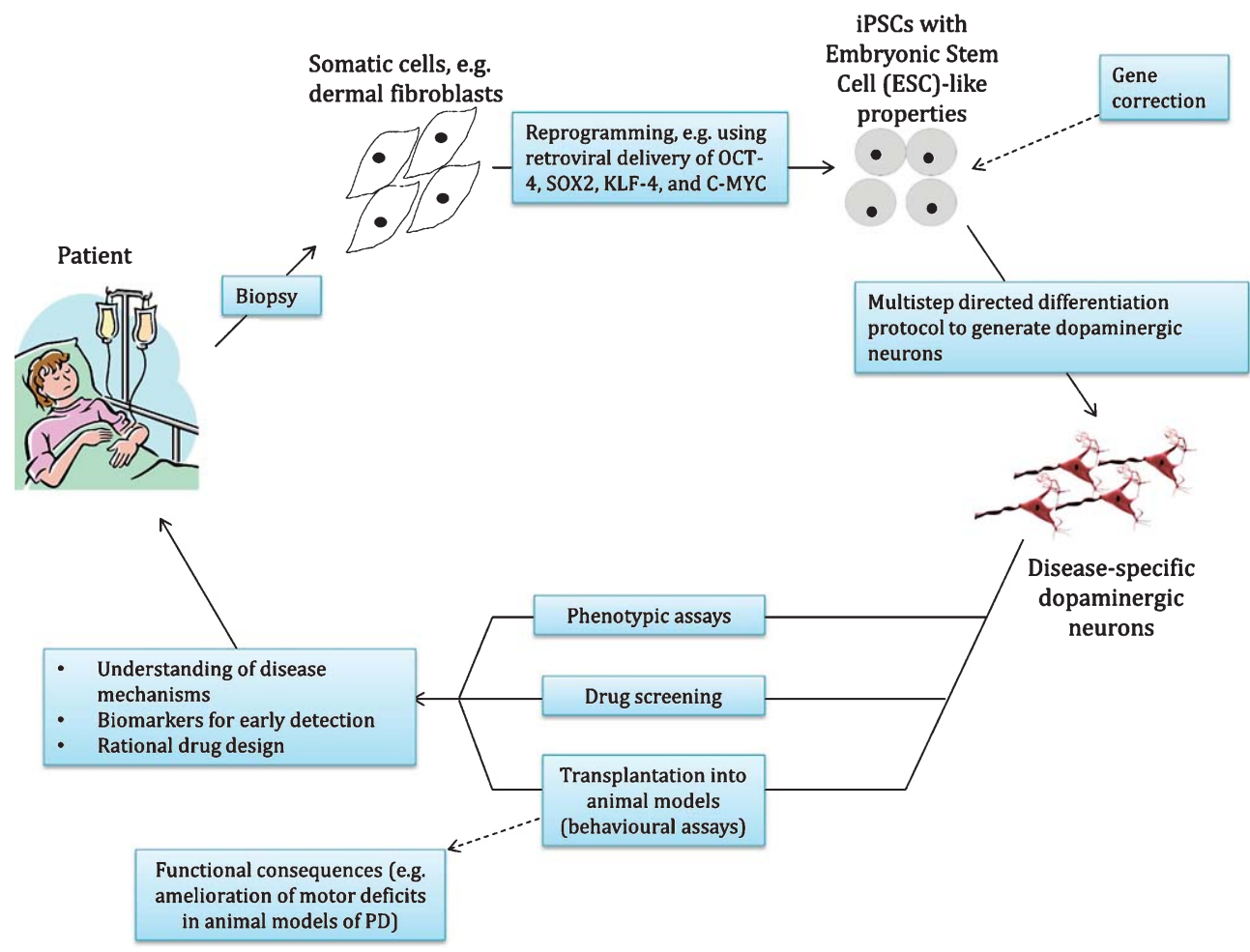

Fig. 1. The iPSC paradigm for modelling PD and other neurodegenerative diseases.

Table 1

Feature of using iPSC-derived neurons

Theoretically-unlimited source of patient-specific cells

Can generate specific cell types

Potential for high-throughput assays

Endogenous levels of gene expression

Capture whole disease genome without age- and

damage-related epigenetic alterations

Derived from fibroblasts/somatic cells
Why is it useful?

Cannot extract live neurons from patients. Finite number of neurons obtained from primary culture.

Can model cell type-specific vulnerability (i.e. of A9 nigral dopaminergic neurons in PD).

Could be used for drug screens (both for general drug discovery and for assessing individual patients' responsiveness to different compounds). Powerful approach for detecting disease phenotypes.

More physiological relevance than overexpression and transgenic models.

Can be used to model earliest stages of disease pathogenesis.

Can avoid ethical issues of embryonic stem cell technology.

Table 2

\begin{tabular}{lc}
\hline Gene/Protein & $\begin{array}{c}\text { Autosomal Dominant/ Autosomal } \\
\text { Recessive (AD/AR) }\end{array}$ \\
\hline Leucine-Rich Repeat Kinase 2 (LRRK2) [9-13,36,38] & $\mathrm{AD}$ \\
$\alpha$-synuclein (SNCA) [14, 15, 41, 42] & $\mathrm{AD}$ \\
Parkin (PARK2) [16-18] & $\mathrm{AR}$ \\
PTEN-induced putative kinase 1 (PINK1) [11, 19, 20] & $\mathrm{AR}$ \\
Glucocerebrosidase (GBA) [21] & $\mathrm{AR}$ \\
\hline
\end{tabular}


other models, iPSCs will be a useful tool for uncovering the mechanisms of PD pathogenesis, testing therapeutic compounds, and facilitating early diagnosis.

\section{IPSC REVOLUTION}

Yamanaka's pioneering experiments demonstrated that somatic cells could be reprogrammed into pluripotency by using retroviral-mediated gene delivery of pluripotent genes OCT4, KLF4, SOX2 and cMYC [3, 4]. iPSCs can theoretically be used to generate unlimited yields of patient-specific neurons or glia in vitro for phenotypic assays and/or drug screening (Fig. 1). These cells have several features that make them an attractive system for modeling neurodegenerative diseases like PD (Table 1).

Alternative cellular systems for modelling PD include classical cell lines (such as HEK293 and the neuroblastoma line SH-SY5Y), human Embryonic Stem Cells (hESCs), and primary cultures of neurons from animal models [5]. As iPSCs can be used to generate 'vulnerable' neuronal subtypes (in particular A9 nigral DAn) from patients with the disease, they offer an unprecedented insight into cell-type specific pathology which cell lines and primary cultures cannot match. hESCs can also be differentiated into A9 DAn, however unlike iPSCs they cannot be derived from somatic cells and so are far more limited in their potential applications for research and therapy.

\section{HOPE AND HYPE: THE STORY SO FAR}

The first few groups to apply the iPSC technology to neurodegenerative observed no overt disease-related phenotypes in patient-derived neurons [6-8]. More recently, distinct phenotypes have been described in neurons generated from patients with $\mathrm{PD}, \mathrm{AD}$, and other conditions [9-36] (Table 3, Supplementary Table 1). Attempts to model PD using iPSCs have focused on familial forms of the disease caused by rare mutations (or multiplications in the case of SNCA) in various genes (Table 2).

What have iPSC-based studies taught us about PD? To answer this question, it is useful to do a thought experiment: if we think of these studies as comprising an isolated body of evidence, what could we learn from it alone? This is inevitably artificial, as progress in PD research relies on a variety of complementary disease models. It is also difficult to synthesise the findings of iPSC-based studies into a coherent whole as individual groups use different differentiation proto- cols, genotypes, and assays. Nevertheless, asking this question forces us to acknowledge that the results from iPSC-based studies of PD (summarised in Table 3 \& Fig. 2) do not yet give us a clear, overarching picture of PD pathogenesis. The interesting and controversial findings of these studies are discussed below.

\section{LRRK2}

As LRRK2 mutations are the most common cause of familial PD [37], the function of this protein has been intensely studied in patient-specific iPSCderived neurons [9-13, 36]. Mutations in LRRK2 have been linked to accumulation of $\alpha$-synuclein-the main protein component of Lewy bodies [37] - and it is therefore noteworthy that four studies have found increased levels of $\alpha$-synuclein protein in patient-derived LRRK2-mutant neurons [9, 10, 13, 36]. Accumulation of $\alpha$-synuclein could be due to increased transcription, increased translation, or decreased degradation. Although Nguyen's group found that SNCA transcription was increased in LRRK2-mutant neurons [9], other groups found no such upregulation $[10,36]$. This disparity may be due to a difference in technique (RT-PCR vs. single-cell RTPCR), neuronal age, genotype, endogenous variability in SNCA expression, or heterogeneity of the neural populations under study. The effect of mutant LRRK2 on SNCA expression is therefore not clear from these studies.

Recent work suggests that mutant LRRK2 could increase $\alpha$-synuclein levels by disrupting chaperonemediated autophagy (CMA) - a pathway via which $\alpha$-synuclein is degraded [13]. This study found that co-localisation of $\alpha$-synuclein with a lysosomal marker was increased in LRRK2-mutant neurons, suggesting that $\alpha$-synuclein accumulates at lysosomes when it is not efficiently degraded. However, inhibition of CMA had a more pronounced effect on $\alpha$-synuclein levels in LRRK2-mutant neurons than controls (in 3 week-old cells), implying that CMA is more active in the mutant neurons at this stage [13]. The elevated $\alpha$-synuclein levels found in the mutant neurons therefore cannot be attributed to defective CMA. Taken together, these studies show that mutant LRRK2 is associated with $\alpha$ synuclein accumulation in iPSC-derived neurons, but the mechanism for this remains unclear.

Morphological defects have also been observed in LRRK2-mutant patient-specific neurons [10, 13, 36]. In one study, the number and length of neurites was found to be decreased in old LRRK2-mutant Dan-a phenotype that was mimicked by overexpression of 


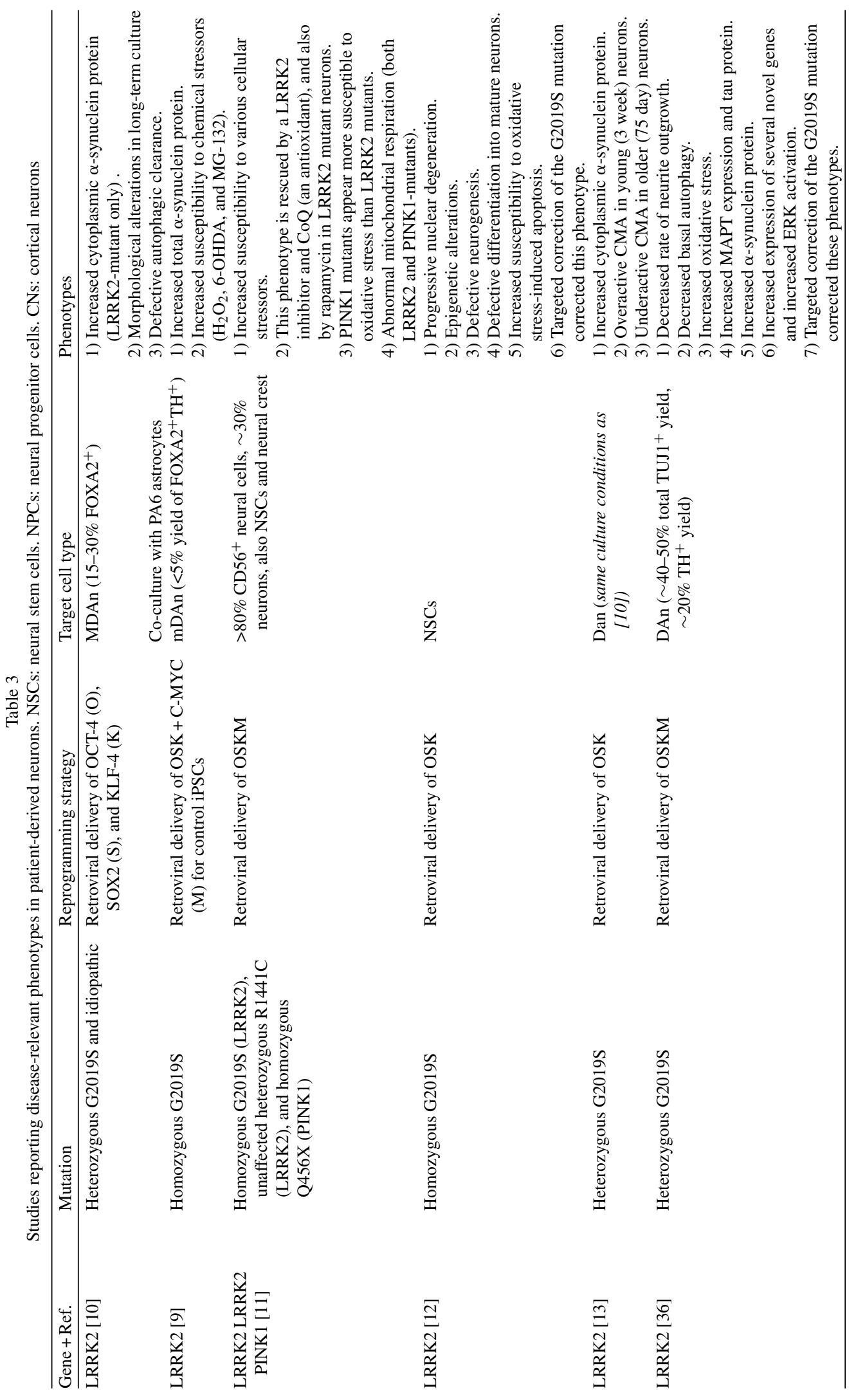




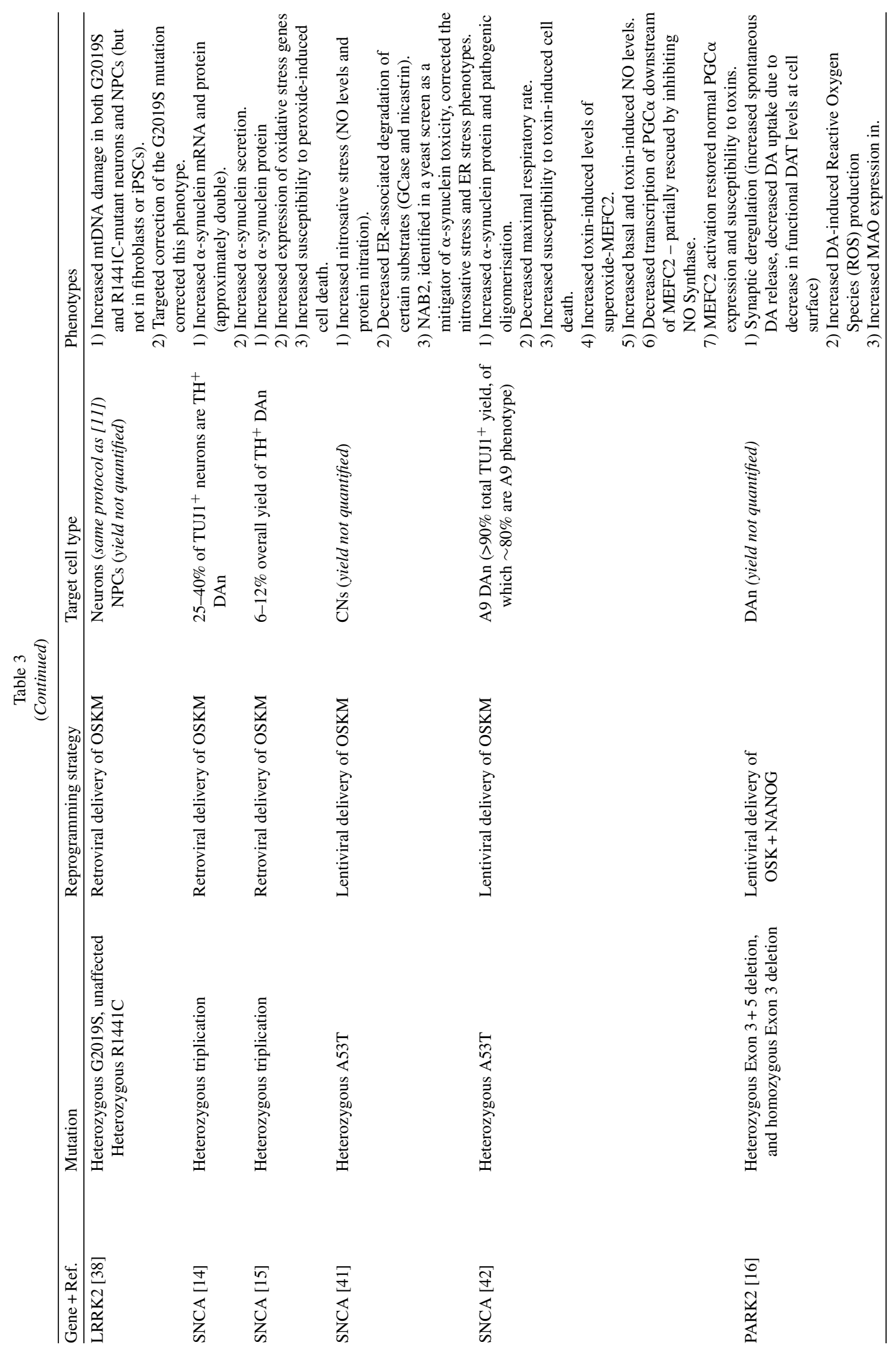




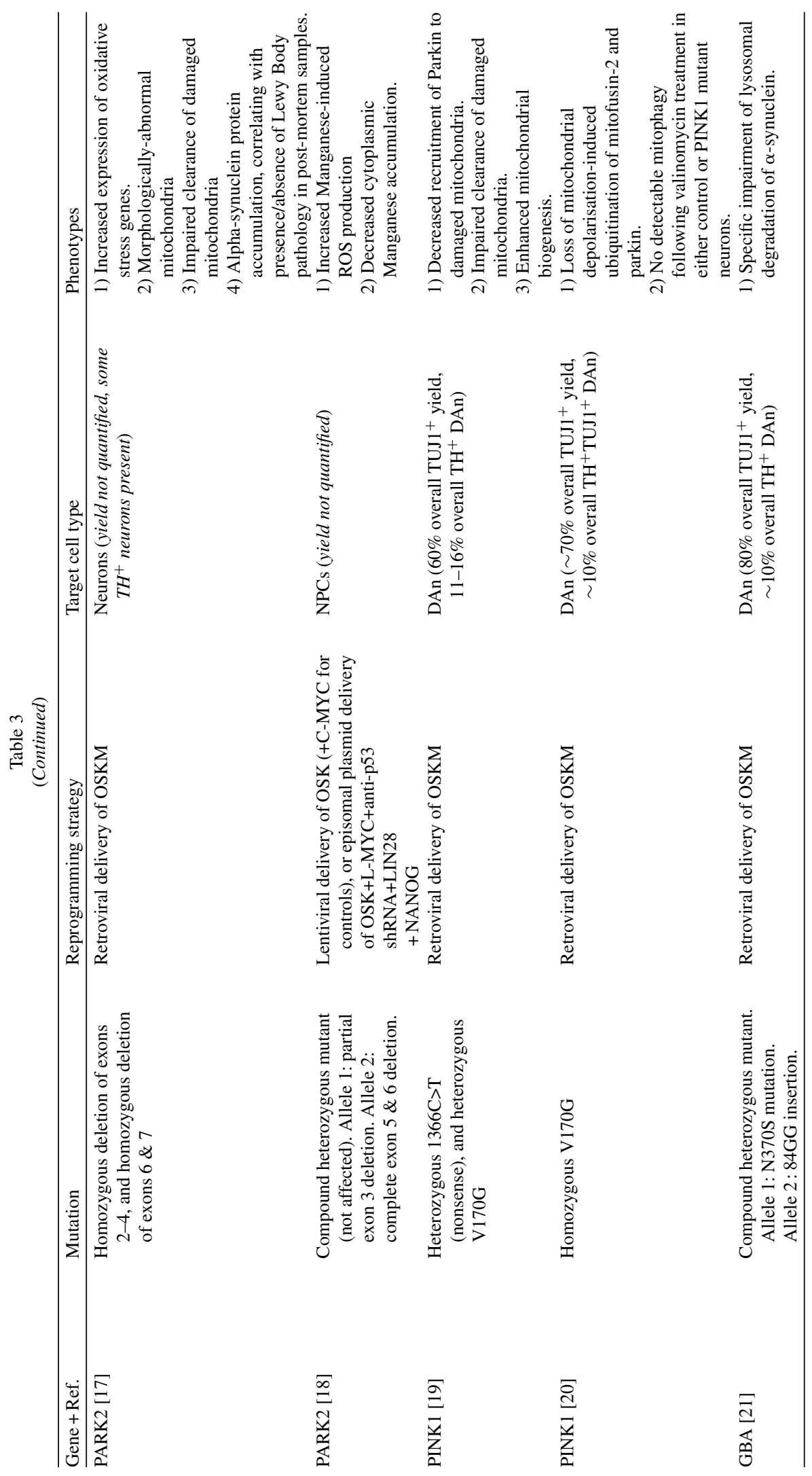




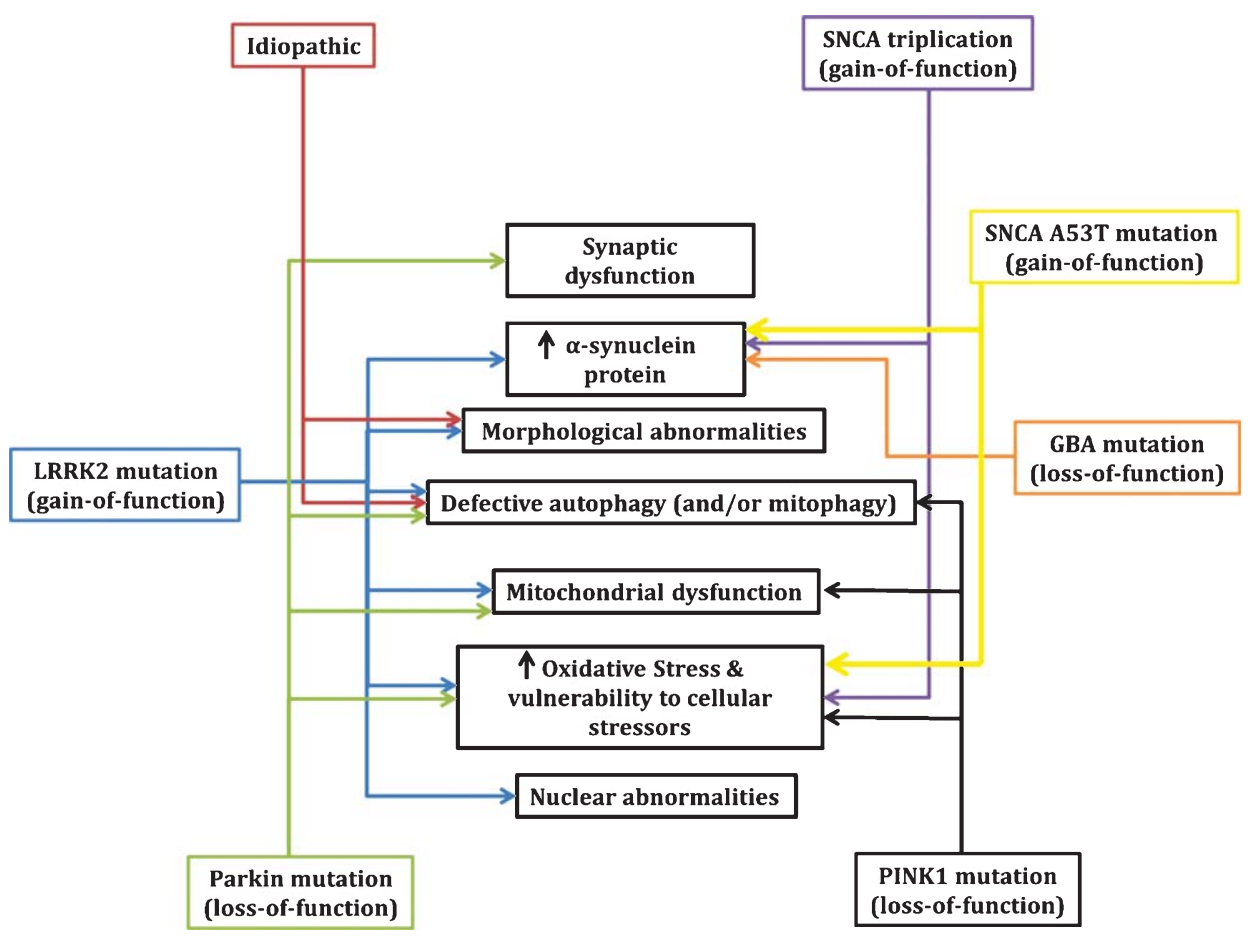

Fig. 2. Phenotypes reported in PD patient-derived neurons.

mutant LRRK2 in control neurons [10]. Another study showed that neurite outgrowth velocity was decreased in LRRK2-mutant DAn, and that this defect could be reversed by targeted correction of the LRRK 2 mutation [36]. These results show that mutant LRRK2 disrupts neuronal morphology, although it is unclear how. The mechanism could involve a combination of overactive ERK signaling [36], downstream changes in gene expression [36], and defective autophagy [10].

LRRK2 mutations may exacerbate oxidative stress in neurons. One study found that the expression of oxidative stress-related genes, e.g., Monoamine Oxidase-B (MAO-B) was increased in LRRK2-mutant neurons compared to controls [9]. In addition, older patient-derived neurons show signs of basal stress: the proportion of LRRK2-mutant DAn undergoing apoptosis (indicated by staining for cleaved Caspase 3, CASP3) was found to be higher than for control DAn [10]. These results suggest that LRRK2 mutations increase basal oxidative stress in neurons. Furthermore, LRRK2-mutant DAn show increased susceptibility to cellular stressors $[9,11,36]$, although there is some disagreement about the precise susceptibility phenotype. Nguyen's group found that LRRK2-mutant neurons were more susceptible to 6OHDA, MG-132 (a proteasomal inhibitor), and $\mathrm{H}_{2} \mathrm{O}_{2}$ than control neurons, whereas Cooper's study found that LRRK2 mutations do not affect susceptibility to these stressors. This discrepancy is probably due to a few factors. Cooper used a shorter drug incubation period (20 hours vs. 48 hours), older cells (56-day vs. 35-day), a different genotype, a smaller maximal dose of $\mathrm{H}_{2} \mathrm{O}_{2}$, and different readouts for cell stress. Perhaps most importantly, Cooper's study was looking at the whole neuronal culture, whereas Nguyen's study distinguished between $\mathrm{TH}+$ and $\mathrm{TH}$ - cells.

Oxidative stress and mitochondrial dysfunction are intimately related. Interestingly, Cooper's study found that the basal and maximal mitochondrial respiration rates were lower in LRRK2-mutant neurons compared to controls [11]. On a related note, a recent application of gene-correction technology to iPSC-derived neurons highlighted a causal link between the presence of the G2019S LRRK2 mutation and the accumulation of damage to mitochondrial DNA [38]. By using live-cell imaging and a fluorescent mitochondrial dye, Cooper's study also found that the proportion of mitochondria showing 'random' back-and-forth movement was greater in LRRK2-mutant neurons [11]. Deregulation of mitochondrial mobility might impair neurons' ability to meet local energy requirements and thus may contribute to oxidative stress [39]. An overall picture 
is emerging in which the mitochondrion is a central target in LRRK2-mediated pathology.

LRRK2 mutations have recently been shown to impact on nuclear structure and function in iPSC-derived neural stem cells (NSCs) [12]. This study found that expression of mutant LRRK2 was associated with aberrant nuclear morphology and disorganisation of the nuclear envelope in late-passage NSCs. Furthermore, LRRK2-mutant NSCs were more susceptible to MG-132 treatment and differentiated less efficiently into neurons than control NSCs. This study elegantly proved that mutant LRRK2 is responsible for these defects by using an adenovirus- based method to correct the G2019S mutation in the patientderived iPSCs - this isogenic control line showed none of the mutant phenotypes mentioned. Despite its neatness, this study is not particularly helpful for understanding how mutant LRRK2 causes disease in adult neurons due to the choice of cell-type - the physiological relevance of using NSCs to model DAn for PD is unclear.

\section{SNCA}

Mutations and multiplications of the SNCA gene are associated with familial PD [2], and triplications cause a fully-penetrant, particularly aggressive, early-onset form of the disease [40]. Two groups have generated iPSC- derived neurons from patients with the SNCA triplication $[14,15]$. Devine's study demonstrated that patient-derived neurons contain at least twice as much $\alpha$-synuclein mRNA and protein as control neurons [14]. The study by Byers and colleagues also found increased $\alpha$-synuclein protein in patient-derived neurons, but found no significant difference in SNCA expression between these neurons and the controls [15]. SNCA expression is most probably increased in the SNCA-triplicate neurons - the Devine et al. findings are more convincing as their expression data are normalised to markers of neuronal differentiation to ensure that similar populations of neurons are being compared. A major caveat with this study, however, is that there is no clear demonstration of $\alpha$-synuclein expression in dopaminergic neurons, merely in $\mathrm{TH}^{+}$ neurons. It would be helpful to clarify this question in purer cultures of A9 DAn.

What are the functional implications of the SNCA triplication? SNCA-triplicate neurons may be more prone to oxidative stress. Byers and colleagues found that the expression of several oxidative stress-related genes (e.g. MAO-A) was up-regulated in patientderived neurons, and that neurons derived from one of the two patients were more susceptible to $\mathrm{H}_{2} \mathrm{O}_{2}$ treatment than controls. There is therefore some evidence that triplication at the SNCA locus increases oxidative stress in neurons, but because the triplication affects a large region of the genome, we cannot rule out the possibility that this phenotype is caused by genes other than SNCA [14, 15]. Additionally, this phenotype may vary substantially between clones as only two were tested.

Two recent studies have examined the phenotype of A53T-mutant neurons [41, 42]. Using a fluorescent indicator to measure intraneuronal $\mathrm{NO}$ and immunostaining to measure levels of protein nitration, Chung et al. found that both of these metrics were increased in A53T-mutant neurons compared to isogenic control lines, suggesting that the SNCA mutation causes a greater degree of nitrosative stress. Higher basal and toxin-induced NO levels were also found in the study by Ryan et al. What is the functional significance of the enhanced nitrosative and oxidative stress phenotype? Ryan's study found that the transcription factor MEFC2 is subject to inactivating modifications by free radicals - a major mechanism appears to be S-nitrosylation of the Cys39 residue in $\alpha$-synuclein. Additionally, transcription of genes downstream of MEFC2 (including PGC1 $\alpha$ ) is decreased in the A53Tmutant neurons - a phenotype which was partially rescued by L-NAME, an inhibitor of Nitric Oxide Synthase (NOS). Incredibly, activating MEFC2 in these neurons using isoxazole almost completely prevented the effects of various mitochondrial toxins such as rotenone. These recent advances are extremely promising examples of how iPSC-derived neurons can be used to pinpoint and manipulate pathological phenotypes in PD.

\section{PARK2 and PINK1}

Mutations in PARK2/parkin and PINK1 are associated with early-onset, AR PD [1]. Parkin and PINK1 are thought to form a mitochondrial qualitycontrol system whereby parkin is recruited to damaged mitochondria in a PINK1-dependent manner and subsequently initiates mitophagy [43]. Several studies have used patient-derived neurons to examine how mutations in these genes cause PD.

PARK2 mutations may predispose neurons to oxidative stress [16-18]. One study found that basal levels of reactive oxygen species (ROS), measured with the fluorescent ROS indicator $2^{\prime}, 7^{\prime}$ dichlorodihydrofluorescein (DCF), were significantly higher in PARK2-mutant neurons than in controls [17]. 
In contrast, another group found that PARK2-mutant neurons showed no signs of increased basal oxidative stress, which they measured indirectly by quantifying the protein carbonyl content of the neurons [16].

What seems clear is that these neurons display increased susceptibility to oxidative stress following treatment with dopamine (DA) [16]. This is intriguing as PARK2-mutant neurons show enhanced spontaneous DA release and decreased DA uptake, implying that these neurons experience elevated extracellular DA levels in vivo. Another study showed that these neurons produced more ROS than controls following treatment with Manganese - exposure to which is an environmental risk factor for PD [18]. Taken together, these results strongly imply that parkin mutations increase neuronal susceptibility to oxidative stress, but the details of the exact phenotype are still unclear. Similarly, PINK1-mutant neurons are more sensitive than controls to a variety of stressors (Table 3) [11]. Intriguingly, this enhanced sensitivity is abolished by treatment with a LRRK2 inhibitor, suggesting that LRRK2 may be involved in neuronal death resulting from mutations in PINK1.

The phenotypes of PARK2 and PINK1-mutant neurons lend support to the idea that these proteins function together to mediate effective clearance of damaged mitochondria. Impaired mitophagy has been observed in PARK2-mutant neurons, albeit indirectly [17]. Imaizumi et al. found that, following mitochondrial depolarisation, the total inner mitochondrial membrane area was decreased in control, but not PARK2-mutant neurons. Seibler et al. demonstrated that mitochondrial depolarisation triggered recruitment of parkin to mitochondria in control but not PINK1-mutant DAn - a defect that was abolished by overexpressing wild-type (WT) PINK1 [19]. Furthermore, mitochondrial depolarisation led to a decrease in the mitochondrial DNA copy number (a measure of the number of mitochondria) in control but not PINK1-mutant DAn. These results suggest that PINK1- dependent recruitment of parkin to mitochondria is essential for effective mitophagy, and that this system is disrupted in neurons by mutation of either of these genes. However, parkin was overexpressed in Seibler's study and it is possible that the observed differences in mitophagy between mutant and control neurons might be an artefact reflecting variable transfection efficiency. In this vein, a recent study [20] found that endogenous parkin is insufficient for triggering mitophagy in iPSC-derived neurons, calling into question the validity of Seibler's and Imaizumi's methods for assessing mitophagy.

\section{CHALLENGES AND OPPORTUNITIES}

iPSC-based models of PD have not lived up to their full potential. Patient-derived neurons display some interesting and relevant phenotypes, but they have not yet yielded any truly original insights into the mechanisms of PD, nor do they seem like a reliable platform for drug screening or diagnosis in their current form. What is holding this work back, and how can these limitations be overcome?

First, iPSC lines display considerable phenotypic variability that is unrelated to their genotype. This 'inter-clonal variability' makes iPSCs an inherently noisy system to work with. Detecting subtle diseaserelevant phenotypes with iPSC-derived neurons is therefore a major challenge - the 'signal-to-noise' ratio in the system is very low. By generating multiple lines from each patient and only comparing lines that differentiate with similar efficiency, this variability can be controlled [14]. Developing more efficient differentiation and reprogramming strategies will also help to remedy this problem.

Second, the genetic and epigenetic profile of iPSCderived neurons may not accurately resemble that of mature neurons. iPSCs commonly display genetic aberrations (e.g. copy number variations [43, 44], somatic coding mutations [45], and chromosomal defects [46]), and epigenetic abnormalities (e.g., X chromosome-reactivation [47] in female cells and transcriptional 'memory' of the cell type from which they are derived [48-51]). The functional impact of these abnormalities on the physiology of iPSC-derived neurons is unclear, although it seems reasonable to assume that, given their frequency, they will have some impact on cell function. A related concern is that in vitro differentiation protocols may not produce neurons with a mature phenotype. The most practical solution to these problems is to implement rigorous criteria for selecting which iPSC and iPSC-derived neuronal lines to experiment on, e.g. those detailed in Fig. 3.

Third, in the majority $(\sim 97 \%)$ of cases PD is not monogenic, but instead results from the interplay of environmental factors and multiple genetic susceptibility loci [2]. Understanding disease pathogenesis in these so-called sporadic or idiopathic cases is therefore essential. But almost all iPSC-based models of PD have focused on familial forms of the disease [9, 11-21, 36]. Study of these rare forms may shed some light on the pathogenesis of sporadic PD, e.g. by highlighting common phenotypes that result from different genetic defects (see Fig. 2). However, a far more direct approach is required to fully understand how gene- 
environment interactions cause PD in sporadic cases. More work should be done using iPSC-derived neurons from sporadic PD patients and from unaffected subjects carrying PD-associated mutations. This avenue of inquiry has already proven fruitful for sporadic PD [10] and sporadic AD [23].

Fourth, given that variations at multiple genetic loci influence the risk of developing PD, great care must be taken when selecting control subjects for iPSC-based studies [2]. To isolate the effect of a rare mutation, e.g., the G2019S substitution in LRRK2, the most adequate control would be an isogenic line with the mutation repaired but exactly the same genetic background. Proof-of-concept studies have shown that Zinc Finger Nucleases (ZFNs) [52] and Transcription ActivationLike Effector Nucleases (TALENs) [53] can be used to correct disease- causing mutations in iPSCs, and to introduce these mutations into control lines. Genomeediting has already been elegantly used to establish a causal relationship between genotype and phenotype in iPSC-derived neurons from PD patients [12, 36, 38, 41, 42] and Huntington's disease patients [25]. Reinhardt et al. demonstrated the power of this approach by discovering a variety of new phenotypes caused by the mutant LRRK2 protein that could not be detected by comparing neurons derived from patients and control subjects [36].

A further issue is that current differentiation protocols generate heterogeneous neural populations, often with low $(<10 \%)$ yields of DAn. To fully understand why PD pathology has such a predilection for A9 nigral DAn, we need better methods of isolating this neural subtype. One solution is to tinker with the patterning factors used during differentiation, e.g. by overexpressing midbrain transcription factors such as LMX1A [54]. New differentiation protocols can achieve an impressive yield of A9 DAn [42]. Alternatively, Fluorescence Activated Cell Sorting (FACS) can be used to purify neurons, as has been done for iPSC-derived neurons from patients with $\mathrm{AD}$ [23] and Amyotrophic Lateral Sclerosis [33]. Another strategy is to bypass the iPSC stage altogether and directly convert skin fibroblasts into DAn $[55,56]$. At present, the efficiency of direct conversion is too low to justify its use over iPSC-derived neurons, as iPSCs have the advantage of being self-renewing and thus an unlimited source of cells. Additionally, both the iPSC and direct conversion approaches are based on bombarding cells viral vectors carrying transcription factors. It is possible that viral reprogramming impacts on the genome in an as yet unspecified way, and thereby might distort the biology of cells derived in this way. Non-integrative technolo- gies (such as episomal vectors, Sendai virus, mirRNA, and mRNA) can offer a complementary, alternative system to bypass this issue.

In a sense an opposite concern is that PD pathogenesis may involve interactions between neurons and glia [57] which cannot be modelled by generating neurons alone. The simplest solution to this problem is to generate patient-specific glial cells in a similar manner, e.g. as was done with astrocytes to study HD [30] and microglia to study Frontotemporal Dementia [35]. Careful co-culture of patient-derived neurons with patient-derived glia will no doubt prove extremely useful as a system for modelling neuronglia interactions. Steps have already been taken in this direction by Henderson and colleagues who showed that iPSC-derived astrocytes promoted hESC-derived motorneurons in vitro, providing a fascinating platform for ALS research [58].

There is also skepticism about whether PD, which usually takes $>60$ years to develop in vivo, can be modelled in vitro over a timescale of less than a year. Maintaining neurons for longer in vitro, e.g. by coculturing with mouse astrocytes [10], sidesteps this problem to an extent. Another solution might be to combine iPSC-derived neurons with animal models; grafting these cells into rats or mice would allow for long-term analysis of their physiology in vivo, as has already been done for PD [59] and HD [28].

An interesting question is whether iPSC-derived neurons could ever be a feasible diagnostic and clinical tool. Could somatic cells be routinely harvested from patients with neurodegenerative disease, reprogrammed into the cell type of choice, and used to inform treatment? This 'personalised iPSC paradigm' could work either by facilitating an accurate pathological diagnosis of different disease subtypes (which may be associated with different responses to certain treatments) or by acting as a platform for drug screens. The equipment and labour costs of the iPSC approach mean that direct clinical applications of this technology on a grand scale are still some way off. However, if costs can be driven down (e.g., by optimizing differentiation protocols) and if more work is done on therapeutic applications of iPSCs (e.g., adapting iPSCderived neurons for rapid compound screens), these cells may well find their way into clinical practice in the future.

\section{OUTLOOK}

The use of iPSC-derived neurons to model PD is still in its infancy. Critics of this technology rightly 
point out that it is a highly ambitious project to attempt to model in vitro any disorder with complex aetiology. Nonetheless, iPSCs hold great promise for PD research. Armed with a combination of non-integrating reprogramming strategies, stringent cell-selection criteria, better differentiation protocols, neuronal purification techniques, genome-editing strategies, in vivo transplantation, international iPSC banks [60], and high-throughput screening of compounds, researchers will be able to harness the full potential of iPSC-derived neurons. Despite its shortcomings, the iPSC technology is an invaluable weapon in the arsenal of those trying to understand the molecular events at the heart of PD pathogenesis.

\section{CONFLICT OF INTEREST}

The authors have no conflict of interest to report.

\section{SUPPLEMENTARY MATERIAL}

Supplementary material is available in the electronic version of this article: http://dx.doi.org/10.3233/JPD130268.

\section{REFERENCES}

[1] de Lau LM, \& Breteler MM (2006) Epidemiology of Parkinson's disease. Lancet Neurol, 5, 525-535.

[2] Shulman JM, De Jager PL, \& Feany MB (2011) Parkinson's disease: Genetics and pathogenesis. Annu Rev Pathol, 6, 193 222.

[3] Takahashi K, \& Yamanaka S (2006) Induction of pluripotent stem cells from mouse embryonic and adult fibroblast cultures by defined factors. Cell, 126, 663-676.

[4] Takahashi K, Tanabe K, Ohnuki M, Narita M, Ichisaka T, Tomoda K, \& Yamanaka S (2007) Induction of pluripotent stem cells from adult human fibroblasts by defined factors. Cell, 131, 861-872.

[5] Alberio T, Lopiano L, \& Fasano M (2012) Cellular models to investigate biochemical pathways in Parkinson's disease. FEBS J, 279, 1146-1155.

[6] Park IH, Arora N, Huo H, Maherali N, Ahfeldt T, Shimamura A, Lensch MW, Cowan C, Hochedlinger K, \& Daley GQ (2008) Disease-specific induced pluripotent stem cells. Cell, 134, 877-886.

[7] Dimos JT, Rodolfa KT, Niakan KK, Weisenthal LM, Mitsumoto H, Chung W, Croft GF, Saphier G, Leibel R, Goland R, Wichterle H, Henderson CE, \& Eggan K (2008) Induced pluripotent stem cells generated from patients with ALS can be differentiated into motor neurons. Science, 321, 12181221.

[8] Soldner F, Hockemeyer D, Beard C, Gao Q, Bell GW, Cook EG, Hargus G, Blak A, Cooper O, Mitalipova M, Isacson O, \& Jaenisch R (2009) Parkinson's disease patient-derived induced pluripotent stem cells free of viral reprogramming factors. Cell, 136, 964-977.
[9] Nguyen HN, Byers B, Cord B, Shcheglovitov A, Byrne J, Gujar P, Kee K, Schule B, Dolmetsch RE, Langston W, Palmer TD, \& Pera RR (2011) LRRK2 mutant iPSC-derived DA neurons demonstrate increased susceptibility to oxidative stress. Cell Stem Cell, 8, 267-280.

[10] Sanchez-Danes A, Richaud-Patin Y, Carballo-Carbajal I, Jimenez-Delgado S, Caig C, Mora S, Di Guglielmo C, Ezquerra M, Patel B, Giralt A, Canals JM, Memo M, Alberch J, Lopez-Barneo J, Vila M, Cuervo AM, Tolosa E, Consiglio A, \& Raya A (2012) Disease-specific phenotypes in dopamine neurons from human iPS-based models of genetic and sporadic Parkinson's disease. EMBO Mol Med, 4, 380395.

[11] Cooper O, Seo H, Andrabi S, Guardia-Laguarta C, Graziotto J, Sundberg M, McLean JR, Carrillo-Reid L, Xie Z, Osborn T, Hargus G, Deleidi M, Lawson T, Bogetofte H, Perez-Torres E, Clark L, Moskowitz C, Mazzulli J, Chen L, VolpicelliDaley L, Romero N, Jiang H, Uitti RJ, Huang Z, Opala G, Scarffe LA, Dawson VL, Klein C, Feng J, Ross OA, Trojanowski JQ, Lee VM, Marder K, Surmeier DJ, Wszolek ZK, Przedborski S, Krainc D, Dawson TM, \& Isacson O (2012) Pharmacological rescue of mitochondrial deficits in iPSCderived neural cells from patients with familial Parkinson's disease. Sci Transl Med, 4, 141ra190.

[12] Liu GH, Qu J, Suzuki K, Nivet E, Li M, Montserrat N, Yi F, Xu X, Ruiz S, Zhang W, Wagner U, Kim A, Ren B, Li Y, Goebl A, Kim J, Soligalla RD, Dubova I, Thompson J, Yates J, 3rd, Esteban CR, Sancho-Martinez I, \& Izpisua Belmonte JC (2012) Progressive degeneration of human neural stem cells caused by pathogenic LRRK2. Nature, 491, 603-607.

[13] Orenstein SJ, Kuo SH, Tasset I, Arias E, Koga H, FernandezCarasa I, Cortes E, Honig LS, Dauer W, Consiglio A, Raya A, Sulzer D, \& Cuervo AM (2013) Interplay of LRRK2 with chaperone-mediated autophagy. Nat Neurosci, 16, 394-406.

[14] Devine MJ, Ryten M, Vodicka P, Thomson AJ, Burdon T, Houlden H, Cavaleri F, Nagano M, Drummond NJ, Taanman JW, Schapira AH, Gwinn K, Hardy J, Lewis PA, \& Kunath T (2011) Parkinson's disease induced pluripotent stem cells with triplication of the alpha-synuclein locus. Nat Commun, 2, 440 .

[15] Byers B, Cord B, Nguyen HN, Schule B, Fenno L, Lee PC, Deisseroth K, Langston JW, Pera RR, \& Palmer TD (2011) SNCA triplication Parkinson's patient's iPSC-derived DA neurons accumulate alpha-synuclein and are susceptible to oxidative stress. PLoS ONE, 6, e26159.

[16] Jiang H, Ren Y, Yuen EY, Zhong P, Ghaedi M, Hu Z, Azabdaftari G, Nakaso K, Yan Z, \& Feng J (2012) Parkin controls dopamine utilization in human midbrain dopaminergic neurons derived from induced pluripotent stem cells. Nat Commun, 3, 668.

[17] Imaizumi Y, Okada Y, Akamatsu W, Koike M, Kuzumaki N, Hayakawa H, Nihira T, Kobayashi T, Ohyama M, Sato S, Takanashi M, Funayama M, Hirayama A, Soga T, Hishiki T, Suematsu M, Yagi T, Ito D, Kosakai A, Hayashi K, Shouji M, Nakanishi A, Suzuki N, Mizuno Y, Mizushima N, Amagai M, Uchiyama Y, Mochizuki H, Hattori N, \& Okano H (2012) Mitochondrial dysfunction associated with increased oxidative stress and alpha-synuclein accumulation in PARK2 iPSC-derived neurons and postmortem brain tissue. Mol Brain, 5, 35.

[18] Aboud AA, Tidball AM, Kumar KK, Neely MD, Ess KC, Erikson KM, \& Bowman AB (2012) Genetic risk for Parkinson's disease correlates with alterations in neuronal manganese sensitivity between two human subjects. Neurotoxicology, 33, 1443-1449. 
[19] Seibler P, Graziotto J, Jeong H, Simunovic F, Klein C, \& Krainc D (2011) Mitochondrial Parkin recruitment is impaired in neurons derived from mutant PINK1 induced pluripotent stem cells. $J$ Neurosci, 31, 5970-5976.

[20] Rakovic A, Shurkewitsch K, Seibler P, Grunewald A, Zanon A, Hagenah J, Krainc D, \& Klein C (2013) Phosphatase and tensin homolog (PTEN)-induced putative kinase 1 (PINK1)dependent ubiquitination of endogenous Parkin attenuates mitophagy: Study in human primary fibroblasts and induced pluripotent stem cell-derived neurons. J Biol Chem, 288, 2223-2237.

[21] Mazzulli JR, Xu YH, Sun Y, Knight AL, McLean PJ, Caldwell GA, Sidransky E, Grabowski GA, \& Krainc D (2011) Gaucher disease glucocerebrosidase and alpha-synuclein form a bidirectional pathogenic loop in synucleinopathies. Cell, 146, 37-52.

[22] Yagi T, Ito D, Okada Y, Akamatsu W, Nihei Y, Yoshizaki T, Yamanaka S, Okano H, \& Suzuki N (2011) Modeling familial Alzheimer's disease with induced pluripotent stem cells. Hum Mol Genet, 20, 4530-4539.

[23] Israel MA, Yuan SH, Bardy C, Reyna SM, Mu Y, Herrera C, Hefferan MP, Van Gorp S, Nazor KL, Boscolo FS, Carson CT, Laurent LC, Marsala M, Gage FH, Remes AM, Koo EH, \& Goldstein LS (2012) Probing sporadic and familial Alzheimer's disease using induced pluripotent stem cells. Nature, 482, 216-220.

[24] Shi Y, Kirwan P, Smith J, MacLean G, Orkin SH, \& Livesey FJ (2012) A human stem cell model of early Alzheimer's disease pathology in Down syndrome. Sci Transl Med, 4, 124ra129.

[25] An MC, Zhang N, Scott G, Montoro D, Wittkop T, Mooney S, Melov S, \& Ellerby LM (2012) Genetic correction of Huntington's disease phenotypes in induced pluripotent stem cells. Cell Stem Cell, 11, 253-263.

[26] Induced pluripotent stem cells from patients with Huntington's disease show CAG-repeat-expansion-associated phenotypes (2012). Cell Stem Cell 11, 264-278

[27] Zhang N, An MC, Montoro D, \& Ellerby LM (2010) Characterization of Human Huntington's Disease Cell Model from Induced Pluripotent Stem Cells. PLoS Curr, 2, RRN1193.

[28] Jeon I, Lee N, Li JY, Park IH, Park KS, Moon J, Shim SH, Choi C, Chang DJ, Kwon J, Oh SH, Shin DA, Kim HS, Do JT, Lee DR, Kim M, Kang KS, Daley GQ, Brundin P, \& Song J (2012) Neuronal properties, in vivo effects, and pathology of a Huntington's disease patient-derived induced pluripotent stem cells. Stem Cells, 30, 2054-2062.

[29] Camnasio S, Delli Carri A, Lombardo A, Grad I, Mariotti C, Castucci A, Rozell B, Lo Riso P, Castiglioni V, Zuccato C, Rochon C, Takashima Y, Diaferia G, Biunno I, Gellera C, Jaconi M, Smith A, Hovatta O, Naldini L, Di Donato S, Feki A, \& Cattaneo E (2012) The first reported generation of several induced pluripotent stem cell lines from homozygous and heterozygous Huntington's disease patients demonstrates mutation related enhanced lysosomal activity. Neurobiol Dis, 46, 41-51.

[30] Juopperi TA, Kim WR, Chiang CH, Yu H, Margolis RL, Ross CA, Ming GL, \& Song H (2012) Astrocytes generated from patient induced pluripotent stem cells recapitulate features of Huntington's disease patient cells. Mol Brain, 5, 17.

[31] Koch P, Breuer P, Peitz M, Jungverdorben J, Kesavan J, Poppe D, Doerr J, Ladewig J, Mertens J, Tuting T, Hoffmann P, Klockgether T, Evert BO, Wullner U, \& Brustle O (2011) Excitation-induced ataxin-3 aggregation in neurons from patients with Machado-Joseph disease. Nature, 480, 543-546.
[32] Bilican B, Serio A, Barmada SJ, Nishimura AL, Sullivan GJ, Carrasco M, Phatnani HP, Puddifoot CA, Story D, Fletcher J, Park IH, Friedman BA, Daley GQ, Wyllie DJ, Hardingham GE, Wilmut I, Finkbeiner S, Maniatis T, Shaw CE, \& Chandran S (2012) Mutant induced pluripotent stem cell lines recapitulate aspects of TDP-43 proteinopathies and reveal cell-specific vulnerability. Proc Natl Acad Sci U S A, 109, 5803-5808.

[33] Egawa N, Kitaoka S, Tsukita K, Naitoh M, Takahashi K, Yamamoto T, Adachi F, Kondo T, Okita K, Asaka I, Aoi T, Watanabe A, Yamada Y, Morizane A, Takahashi J, Ayaki T, Ito H, Yoshikawa K, Yamawaki S, Suzuki S, Watanabe D, Hioki H, Kaneko T, Makioka K, Okamoto K, Takuma H, Tamaoka A, Hasegawa K, Nonaka T, Hasegawa M, Kawata A, Yoshida M, Nakahata T, Takahashi R, Marchetto MC, Gage FH, Yamanaka S, \& Inoue H (2012) Drug screening for ALS using patient-specific induced pluripotent stem cells. Sci Transl Med, 4, $145 \mathrm{ra} 104$.

[34] Mitne-Neto M, Machado-Costa M, Marchetto MC, Bengtson MH, Joazeiro CA, Tsuda H, Bellen HJ, Silva HC, Oliveira AS, Lazar M, Muotri AR, \& Zatz M (2011) Downregulation of VAPB expression in motor neurons derived from induced pluripotent stem cells of ALS8 patients. Hum Mol Genet, 20, 3642-3652.

[35] Almeida S, Zhang Z, Coppola G, Mao W, Futai K, Karydas A, Geschwind MD, Tartaglia MC, Gao F, Gianni D, Sena-Esteves M, Geschwind DH, Miller BL, Farese RV Jr, \& Gao FB (2012) Induced pluripotent stem cell models of progranulin-deficient frontotemporal dementia uncover specific reversible neuronal defects. Cell Rep, 2, 789-798.

[36] Reinhardt P, Schmid B, Burbulla LF, Schondorf DC, Wagner L, Glatza M, Hoing S, Hargus G, Heck SA, Dhingra A, Wu G, Muller S, Brockmann K, Kluba T, Maisel M, Kruger R, Berg D, Tsytsyura Y, Thiel CS, Psathaki OE, Klingauf J, Kuhlmann T, Klewin M, Muller H, Gasser T, Scholer HR, \& Sterneckert J (2013) Genetic correction of a LRRK2 mutation in human iPSCs links parkinsonian neurodegeneration to ERK-dependent changes in gene expression. Cell Stem Cell, 12, 354-367.

[37] Cookson MR (2010) The role of leucine-rich repeat kinase 2 (LRRK2) in Parkinson's disease. Nat Rev Neurosci, 11, 791797.

[38] Sanders LH, Laganiere J, Cooper O, Mak SK, Vu BJ, Huang YA, Paschon DE, Vangipuram M, Sundararajan R, Urnov FD, Langston JW, Gregory PD, Zhang HS, Greenamyre JT, Isacson O, \& Schule B (2013) LRRK2 mutations cause mitochondrial DNA damage in iPSC-derived neural cells from Parkinson's disease patients: Reversal by gene correction. Neurobiol Dis, 62C 381-386.

[39] Sheng ZH, \& Cai Q (2012) Mitochondrial transport in neurons: Impact on synaptic homeostasis and neurodegeneration. Nat Rev Neurosci, 13, 77-93.

[40] Singleton AB, Farrer M, Johnson J, Singleton A, Hague S, Kachergus J, Hulihan M, Peuralinna T, Dutra A, Nussbaum R, Lincoln S, Crawley A, Hanson M, Maraganore D, Adler C, Cookson MR, Muenter M, Baptista M, Miller D, Blancato J, Hardy J, \& Gwinn-Hardy K (2003) alpha-Synuclein locus triplication causes Parkinson's disease. Science, 302, 841.

[41] Chung CY, Khurana V, Auluck PK, Tardiff DF, Mazzulli JR, Soldner F, Baru V, Lou Y, Freyzon Y, Cho S, Mungenast AE, Muffat J, Mitalipova M, Pluth MD, Jui NT, Schule B, Lippard SJ, Tsai LH, Krainc D, Buchwald SL, Jaenisch R, \& Lindquist S (2013) Identification and rescue of alpha-synuclein toxicity in Parkinson patient-derived neurons. Science, 342, 983-987. 
[42] Ryan SD, Dolatabadi N, Chan SF, Zhang X, Akhtar MW, Parker J, Soldner F, Sunico CR, Nagar S, Talantova M, Lee B, Lopez K, Nutter A, Shan B, Molokanova E, Zhang Y, Han X, Nakamura T, Masliah E, Yates JR, 3rd, Nakanishi N, Andreyev AY, Okamoto S, Jaenisch R, Ambasudhan R, \& Lipton SA (2013) Isogenic Human iPSC Parkinson's Model Shows Nitrosative Stress-Induced Dysfunction in MEF2PGC1alpha Transcription. Cell, 155, 1351-1364.

[43] Vives-Bauza C, Zhou C, Huang Y, Cui M, de Vries RL, Kim J, May J, Tocilescu MA, Liu W, Ko HS, Magrane J, Moore DJ, Dawson VL, Grailhe R, Dawson TM, Li C, Tieu K, \& Przedborski S (2010) PINK1-dependent recruitment of Parkin to mitochondria in mitophagy. Proc Natl Acad Sci U S A, 107, 378-383.

[44] Laurent LC, Ulitsky I, Slavin I, Tran H, Schork A, Morey R, Lynch C, Harness JV, Lee S, Barrero MJ, Ku S, Martynova M, Semechkin R, Galat V, Gottesfeld J, Izpisua Belmonte JC, Murry C, Keirstead HS, Park HS, Schmidt U, Laslett AL, Muller FJ, Nievergelt CM, Shamir R, \& Loring JF (2011) Dynamic changes in the copy number of pluripotency and cell proliferation genes in human ESCs and iPSCs during reprogramming and time in culture. Cell Stem Cell, 8, 106118.

[45] Gore A, Li Z, Fung HL, Young JE, Agarwal S, AntosiewiczBourget J, Canto I, Giorgetti A, Israel MA, Kiskinis E, Lee JH, Loh YH, Manos PD, Montserrat N, Panopoulos AD, Ruiz S, Wilbert ML, Yu J, Kirkness EF, Izpisua Belmonte JC, Rossi DJ, Thomson JA, Eggan K, Daley GQ, Goldstein LS, \& Zhang K (2011) Somatic coding mutations in human induced pluripotent stem cells. Nature, 471, 63-67.

[46] Mayshar Y, Ben-David U, Lavon N, Biancotti JC, Yakir B, Clark AT, Plath K, Lowry WE, \& Benvenisty N (2010) Identification and classification of chromosomal aberrations in human induced pluripotent stem cells. Cell Stem Cell, 7, 521531.

[47] Mekhoubad S, Bock C, de Boer AS, Kiskinis E, Meissner A, \& Eggan K (2012) Erosion of dosage compensation impacts human iPSC disease modeling. Cell Stem Cell, 10, 595-609.

[48] Polo JM, Liu S, Figueroa ME, Kulalert W, Eminli S, Tan KY, Apostolou E, Stadtfeld M, Li Y, Shioda T, Natesan S, Wagers AJ, Melnick A, Evans T, \& Hochedlinger K (2010) Cell type of origin influences the molecular and functional properties of mouse induced pluripotent stem cells. Nat Biotechnol, $\mathbf{2 8}$ 848-855.

[49] Kim K, Doi A, Wen B, Ng K, Zhao R, Cahan P, Kim J, Aryee MJ, Ji H, Ehrlich LI, Yabuuchi A, Takeuchi A, Cunniff KC, Hongguang H, McKinney-Freeman S, Naveiras O, Yoon TJ, Irizarry RA, Jung N, Seita J, Hanna J, Murakami P, Jaenisch R, Weissleder R, Orkin SH, Weissman IL, Feinberg AP, \& Daley GQ (2010) Epigenetic memory in induced pluripotent stem cells. Nature, 467, 285-290.

[50] Kim K, Zhao R, Doi A, Ng K, Unternaehrer J, Cahan P, Huo H, Loh YH, Aryee MJ, Lensch MW, Li H, Collins JJ, Feinberg AP, \& Daley GQ (2011) Donor cell type can influence the epigenome and differentiation potential of human induced pluripotent stem cells. Nat Biotechnol, 29, 1117-1119.
[51] Ohi Y, Qin H, Hong C, Blouin L, Polo JM, Guo T, Qi Z, Downey SL, Manos PD, Rossi DJ, Yu J, Hebrok M, Hochedlinger K, Costello JF, Song JS, \& Ramalho-Santos M (2011) Incomplete DNA methylation underlies a transcriptional memory of somatic cells in human iPS cells. Nat Cell Biol, 13, 541-549.

[52] Soldner F, Laganiere J, Cheng AW, Hockemeyer D, Gao Q, Alagappan R, Khurana V, Golbe LI, Myers RH, Lindquist S, Zhang L, Guschin D, Fong LK, Vu BJ, Meng X, Urnov FD, Rebar EJ, Gregory PD, Zhang HS, \& Jaenisch R (2011) Generation of isogenic pluripotent stem cells differing exclusively at two early onset Parkinson point mutations. Cell, 146, 318-331.

[53] Hockemeyer D, Wang H, Kiani S, Lai CS, Gao Q, Cassady JP, Cost GJ, Zhang L, Santiago Y, Miller JC, Zeitler B, Cherone JM, Meng X, Hinkley SJ, Rebar EJ, Gregory PD, Urnov FD, \& Jaenisch R (2011) Genetic engineering of human pluripotent cells using TALE nucleases. Nat Biotechnol, 29, 731-734.

[54] Sanchez-Danes A, Consiglio A, Richaud Y, Rodriguez-Piza I, Dehay B, Edel M, Bove J, Memo M, Vila M, Raya A, \& Izpisua Belmonte JC (2012) Efficient generation of A9 midbrain dopaminergic neurons by lentiviral delivery of LMX1A in human embryonic stem cells and induced pluripotent stem cells. Hum Gene Ther, 23, 56-69.

[55] Pfisterer U, Kirkeby A, Torper O, Wood J, Nelander J, Dufour A, Bjorklund A, Lindvall O, Jakobsson J, \& Parmar M (2011) Direct conversion of human fibroblasts to dopaminergic neurons. Proc Natl Acad Sci U S A, 108, 10343-10348.

[56] Caiazzo M, Dell'Anno MT, Dvoretskova E, Lazarevic D, Taverna S, Leo D, Sotnikova TD, Menegon A, Roncaglia P, Colciago G, Russo G, Carninci P, Pezzoli G, Gainetdinov RR, Gustincich S, Dityatev A, \& Broccoli V (2011) Direct generation of functional dopaminergic neurons from mouse and human fibroblasts. Nature, 476, 224-227.

[57] Halliday GM, \& Stevens CH (2011) Glia: Initiators and progressors of pathology in Parkinson's disease. Mov Disord, 26, 6-17.

[58] Roybon L, Lamas NJ, Garcia-Diaz A, Yang EJ, Sattler R, Jackson-Lewis V, Kim YA, Kachel CA, Rothstein JD, Przedborski S, Wichterle H, \& Henderson CE (2013) Human stem cell-derived spinal cord astrocytes with defined mature or reactive phenotypes. Cell Rep, 4, 1035-1048.

[59] Hargus G, Cooper O, Deleidi M, Levy A, Lee K, Marlow E, Yow A, Soldner F, Hockemeyer D, Hallett PJ, Osborn T, Jaenisch R, \& Isacson O (2010) Differentiated Parkinson patient-derived induced pluripotent stem cells grow in the adult rodent brain and reduce motor asymmetry in Parkinsonian rats. Proc Natl Acad Sci U S A, 107, 15921-15926.

[60] Xue Y, Cai X, Wang L, Liao B, Zhang H, Shan Y, Chen Q, Zhou T, Li X, Hou J, Chen S, Luo R, Qin D, Pei D, \& Pan G (2013) Generating a non-integrating human induced pluripotent stem cell bank from urine-derived cells. PLOS ONE, 8, e70573. 